MARTA KUPIS ${ }^{1}$

\title{
TOŻSAMOŚĆ, DOMINACJA I INTERNET - ZAGADNIENIE APROPRIACJI KULTUROWEJ W DYSKURSIE INTERNETOWYM
}

Słowa kluczowe: apropriacja kulturowa, neokolonializm, postkolonializm, globalizacja, władza

W napisanej na początku XXI wieku przedmowie do swojej znanej książki Orientalizm Edward Said z nadzieją wypowiada się o rozwijającym się społeczeństwie cybernetycznym:

Dziś wspomaga nas niezwykła, demokratyczna siła, jaką jest cyberprzestrzeń otwarta dla wszystkich użytkowników w sposób, o jakim nie śniło się wcześniejszym pokoleniom tyranów i ortodoksów².

Internet oraz funkcjonujące za jego pomocą media społecznościowe są obiektem zarówno optymistycznych pochwał, jak powyższa, jak też ostrej krytyki dotyczącej zmian, jakie wywołują. Tym, co nie ulega jednak wątpliwości, jest to, że pod ich wpływem nasiliła się liczebność, a także zmieniła jakość kontaktów międzyludzkich i międzykulturowych. Mylnym byłoby wprawdzie stwierdzenie, jakoby sieć już stanowiła perfekcyjne narzędzie ogólnoświatowej demokracji deliberatywnej czy chociaż w pełni otwartego forum - barierami są na przykład potrzeba znajomości języka angielskiego, posiadania podstawowych kompetencji w obsłudze mediów społecznościowych, a także, o czym łatwo zapomnieć w zachodnim

\footnotetext{
${ }^{1}$ Mgr; Uniwersytet Jagielloński w Krakowie; ORCID: 0000-0002-2279-1881;

e-mail: marta_roksana.kupis@student.uj.edu.pl.

${ }^{2}$ E.W. Said, Orientalizm, przeł. M. Wyrwas-Wiśniewska, Poznań 2005, s. 24.
} 
kręgu kulturowym, kwestia faktycznie wolnego dostępu do cyberprzestrzeni - niemniej jednak obserwując społeczność internetową, można zauważyć, że medium to udzieliło głosu grupom, które tradycyjne przekaźniki często marginalizowały.

Jednym z ciekawszych zagadnień, które wprawdzie nie narodziło się w cyberprzestrzeni, jednak obecnie to ona jest najczęstszą areną dyskusji na jego temat, jest funkcjonujące pod angielską nazwą cultural (mis)appropriation. Samo pojęcie można przetłumaczyć jako kulturowe zawłaszczenie, asygnację lub przypisanie, jednak ze względu na rozległe pole znaczeniowe terminu korzystnym wydaje się używanie zapożyczonego, obcojęzycznego słowa „apropriacja”. Co nawiasem mówiąc, samo w sobie można uznać za akt omawianego tu zjawiska.

Podchodząc do tematu „obiektywnie”, trudno jest bowiem odróżnić kulturową apropriację od zjawisk dyfuzji i wymiany kulturowej. Według internetowego słownika Cambridge zwrot ten jest „krytyczny” i oznacza „akt zabierania lub używania rzeczy należących do kultury, której członkiem się nie jest, zwłaszcza jeżeli nie okazuje się jej zrozumienia lub szacunku"3. $Z$ bardziej subiektywnej perspektywy internetowa publicystka K. Tempest Bradford, osobiście zaangażowana w omawiany temat, zwraca uwagę na inny aspekt: chociaż również twierdzi, że najprostszą definicją pojęcia jest wykorzystywanie elementów obcej kultury, to podkreśla, że

głębsze rozumienie apropriacji kulturowej odnosi się do szczególnej dynamiki władzy, w której członkowie kultury dominującej biorą elementy z kultury ludzi, którzy byli systematycznie uciskani przez tych pierwszych4 .

Widać więc, że kwestia apropriacji kulturowej odnosi się nie tyle do obiektywnych działań, ile raczej do subiektywnych, psychologicznych przeżyć indywidualnych członków poszczególnych grup kulturowych. Celem niniejszego artykułu jest przedstawienie, jak - poprzez dyskusje on-line kształtowane są rozumienie oraz dyskurs wokół apropriacji kulturowej, zaprezentowanie niektórych zachowań krytykowanych w internecie przez

${ }^{3}$ Cambridge Dictionary, https://dictionary.cambridge.org/dictionary/english/cultural-appropriation (dostęp 28 XI 2018). O ile nie zaznaczono inaczej, tłumaczenia z języka angielskiego pochodzą ode mnie - M.K. W cytowanych dalej wypowiedziach internautów zachowuję podkreślenia i nieporadności językowe autorów wpisów.

${ }^{4}$ K.T. Bradford, The Cultural Appropriation Primer, https://medium.com/@tempest/ the-cultural-appropriation-primer-91f1101dae1d (dostęp 28 XI 2018). 
uwrażliwione jednostki jako jej przejawy oraz osadzenie tego typu odczuć w szerszych ramach analizy antropologicznej. Warto dodać, że określenie to raczej nie funkcjonuje wśród polskojęzycznych badaczy, a temat budzi tyle emocji, że wydaje się korzystne przedstawienie go polskim specjalistom. $\mathrm{Na}$ koniec zostaną też zaprezentowane sugestie internautów dotyczące sposobów unikania apropriacji kulturowej, bez rezygnowania przy tym z zachowującego szacunek korzystania z wytworów innych kultur. W tym celu konieczne jest jednak przybliżenie zastosowanych tu terminów badawczych.

Trudno jest rozpatrywać apropriację kulturową w oderwaniu od kwestii grupowej własności intelektualnej, którą charakteryzuje małżeństwo Comaroffów. Łatwo zauważyć, że prowadzone tu rozważania opierają się na postrzeganiu kultury jako czegoś, co można „zabrać” czy „przywłaszczyć” (ale też, jak wskazują wspomniani badacze: sprzedać), przy czym nie chodzi tu bynajmniej o konkretne przedmioty, ale raczej o wzory, zwyczaje, a nawet wiedzę. Indywidualne prawo własności intelektualnej jest obecnie na tyle oczywiste dla człowieka z zachodniego kręgu kulturowego, że trudno sobie uświadomić, iż wywodzi się ono ze świata techniki i obowiązujących tam patentów, które same liczą zaledwie około dwustu lat. To, że wynalazca, badacz czy autor powinien mieć jakąś formę „władzy” nad swoimi dokonaniami, jak również otrzymywać wynagrodzenie z tytułu udostępnienia owoców swojego umysłu dla użytku innych ludzi, wydaje się całkiem oczywiste i uzasadnione. Trudniej jednak przyjąć myśl o tym, że także grupa ludzi może pragnąć podobnych praw wobec swoich wytworów oraz dziedzictwa przodków, dzięki któremu możliwe było ich stworzenie. Niemniej jednak gdy dokładniej przeanalizuje się tę sytuację, widać, że postulaty te nie są bezpodstawne. Bardzo dobry przykład przytaczają Camaroffowie ${ }^{5}-$ opisują oni perypetie południowoafrykańskich Sanów z kaktusem xhoba (jego łacińska nazwa brzmi hoodia gordonii), który znany był Sanom od dawna jako bardzo sycące i krzepiące pożywienie, nawet $w$ niewielkich ilościach. Nie wzbudzało to większego zainteresowania reszty świata, dopóki pracownicy firm farmaceutycznych nie zdali sobie sprawy, że właściwości te mogłyby okazać się kopalnią złota w przemyśle preparatów na odchudzanie. Pod wpływem prawników, którzy wytłumaczyli Sanom, że właściwie to oni pierwsi znali działanie xhoby, rozpoczął się dosyć długi spór, podczas którego w grę wchodziła zarówno tradycyjna, jak i naukowa wiedza

${ }^{5}$ J.L. Comaroff, J. Comaroff, Etniczność sp. z o.o., przeł. W. Usakiewicz, Kraków 2011, s. $107-121$. 
(czy prawo do patentu mają ci, którzy pierwsi odkryli działanie rośliny, czy ci, którzy wyróżnili substancję czynną?), a także kwestia wspomagania gospodarki w krajach Trzeciego Świata. Cała sprawa zakończyła się jednak fiaskiem, gdyż ostatecznie przetworzenie xhoby na tabletki okazało się zbyt trudne, aby jej uprawa komukolwiek miała przynieść fortunę.

Pod lekko ironicznym tonem Comaroffów kryje się mimo wszystko uznanie, że grupowa własność intelektualna istnieje co najmniej tak realnie, jak indywidualna - i jako taka powinna łączyć się chociaż z częścią praw przynależnych „oryginalnym” posiadaczom danej wiedzy (warto podkreślić, że w opisanym wyżej sporze prawie nigdy nie kwestionowano praw Sanów, a gdyby hodowla ruszyła, zajmowaliby się nią głównie oni - co z kolei służyłoby wizerunkowi firm produkujących środki odchudzające). Podobnie jednak jak z patentami i prawami autorskimi w zakresie indywidualnym, bardziej przemawia do wyobraźni prawo do monopolu na uprawę rośliny niż do tantiemów z każdego komercyjnego wyszycia tradycyjnego wzoru na materiale lub otwarcia restauracji z kuchnią innej grupy etnicznej. Nie oznacza to bynajmniej, że pewnym grupom nie udawało się obrócić tych ostatnich w zysk, równocześnie wspomagający ich własną tożsamość. Potomkowie szwedzkich imigrantów w Stanach Zjednoczonych, opisani przez Monikę Banaś w książce Etniczność na sprzedaż ${ }^{6}$, stanowią przykład zarówno sukcesu takiej operacji, jak również tego, że utowarowienie etniczności nie jest zjawiskiem ani nowym, ani ograniczonym do krajów rozwijających się.

Oprócz pojęcia grupowej własności intelektualnej wartymi wprowadzenia są jeszcze dwa inne: tożsamości kulturowej oraz stosunków władzy. Pierwsze jest skądinąd mocno związane z tematem omawianym wyżej - ostatecznie aby móc przypisywać sobie prawo do swobodnego użytkowania chronionych dóbr materialnych czy niematerialnych - jak również określać, jak i kto spoza grupy może z nich korzystać - trzeba najpierw być członkiem danej społeczności. Jednak zamiast usiłować przedstawić obiektywne wyznaczniki przynależności kulturowej, należałoby raczej omówić subiektywną perspektywę, dającą poczucie związku z daną kulturą. Chociaż próba jednoznacznego zdefiniowania, czym jest tożsamość, skazana jest na porażkę, to można wyróżnić elementy, które osadzają ją w kontekście jej funkcjonowania w różnych cywilizacjach. Według Słownika etnologicznego tożsamość kulturowa „polega na historycznie uwarunkowanym,

${ }^{6}$ M. Banaś, Etniczność na sprzedaż, Kraków 2005, s. 74-78. 
kulturowym sposobie zachowania przez daną zbiorowość ludzką istnienia i ciągłości gatunku oraz równowagi biopsychicznej", a składają się na nią: po pierwsze, elementy dziedzictwa, także zdezaktualizowane, po drugie, cechy wyróżniające daną kulturę, jak również ich rozpowszechnienie wśród jej członków, a po trzecie - kontekst relacji z innymi grupami. Zgodnie $z$ dalszą definicją

tożsamość jest skazana definitywnie na wpisanie w obszar pośredni pomiędzy tym, co pojedyncze, i tym, co zbiorowe, tym, co wewnętrzne, i tym, co zewnętrzne, bytem i działaniem, ego i alter, defensywą i ofensywą, zakorzenieniem i migracją, asymilacją i dyskryminacją, wrośnięciem i marginalnością?.

Można więc powiedzieć, że ten nieuchwytnie trwały aspekt ludzkiej osobowości potrzebuje dialektyki pomiędzy tym, co swoje i cudze, między znanym i obcym - przy czym ten drugi element jest jej równie niezbędny, jak pierwszy. Tak jak z własnej unikalności jednostka zdaje sobie sprawę poprzez kontakt z innymi, tak samo nie da się wytworzyć tożsamości grupowej, kulturowej bez dostrzeżenia jej wyjątkowości poprzez kontrast z inną grupą. Równocześnie jednak w ostatnich czasach można zauważyć odwrócenie kierunku budowania tożsamości. O ile przytoczona definicja sugeruje pierwotne istnienie kultury, która przez kontakt z „innym” jest jedynie dookreślana, zyskuje wyrazisty kształt, skłaniana jest do skonkretyzowania, a zarazem umożliwia indywidualnej osobie zdanie sobie sprawy $z$ roli, jaką dana tradycja odgrywa w jej życiu, o tyle obecnie coraz więcej osób poszukuje swojej tożsamości i zakorzenienia w kulturach, w których nie zostały wychowane - co nie oznacza, że do nich nie „należą". Trzeba też bowiem zauważyć, że w dzisiejszych czasach coraz więcej elementów może się stać wyróżnikami przynależności kulturowej: oprócz narodowości, etniczności czy religii rolę centrum tożsamości grupowej może stanowić płeć, orientacja seksualna, sprawność psychofizyczna, a nawet preferowany sposób spędzania wolnego czasu. Czy możliwe, aby kulturowa apropriacja była drugą stroną medalu poszukiwania kulturowej przynależności?

Należy wreszcie przybliżyć kwestię stosunków władzy, wskazanych jako faktyczny wyróżnik apropriacji kulturowej przez Bradford. W kontekście kultury i ucisku najodpowiedniejszymi ramami wydają się teorie Edwarda

7 Słownik etnologiczny: terminy ogólne, red. Z. Staszczak, Warszawa - Poznań 1987, s. 351-352. 
W. Saida, Patricii Hill Collins i Erika O. Wrighta. Dwie pierwsze osadzone są w koncepcji Michela Foucaulta, charakteryzującej władzę nie jako zjawisko posiadające pojedyncze, hegemoniczne centrum, tylko jako „funkcję wielości punktów oporu, które w relacjach władzy pełnią funkcję przeciwnika, celu, podpory, łupu do zdobycia". Jest więc ona tworzona przede wszystkim w relacji, opozycji do czegoś innego, sprzeciwiającego się konkretnemu ośrodkowi. Francuski badacz uważa też, że jednym z głównych narzędzi legitymizacji władzy jest wiedza, rozumiana jako pewna kreacja wyjaśniająca świat w sposób sankcjonujący pozycję określonych grup ${ }^{8}$. Myśl tę rozwinął Said, który we wspomnianym już Orientalizmie pokazuje, jak za pomocą odpowiednich dyskursów zachodni badacze czy autorzy kreowali Wschód, tworząc w umysłach swoich współziomków jego reprezentację, która okazywała się mieć większe wpływy kulturowe niż faktyczne kontakty z mieszkańcami Bliskiego Wschodu. Chociaż książka ta dotyczy konkretnie arabskiego kręgu kulturowego, to przedstawia szersze zagadnienia związane z postkolonializmem, w którym bezpośrednia władza polityczna dawnych imperiów odeszła do historii, ale utrzymuje się zinternalizowane, nie do końca uświadamiane poczucie dominacji nad innymi kulturami oraz „lepszej wiedzy" u obarczonego przez Rudyarda Kiplinga brzemieniem białego człowieka ${ }^{9}$. Collins wprowadza natomiast pojęcie „siatki dominacji”: relacje dominacji i podporządkowania nie są jednokierunkowe, ale stanowią raczej matrycę, w której ta sama osoba może być równocześnie w relacji większej władzy ze względu na jedną część swojej tożsamości i mniejszej ze względu na inną. Autorka charakteryzuje to zjawisko przede wszystkim w kontekście przynależności etnicznej oraz płci. Chociaż teoria Collins zwraca uwagę na to, że dominacja kulturowa nie jest tak jednoznacznie określona, jak mogłoby się wydawać, to zarazem nie neguje tego, że niektóre grupy mogą się w tej siatce znaleźć na wyjątkowo nieuprzywilejowanej pozycji - najlepszym przykładem są wskazywane przez nią w tytule czarnoskóre kobiety ${ }^{10}$. Wright wreszcie przedstawia głęboką analizę tematu ucisku, uznawanego czasem za podstawowe kryterium rozróżniające dyfuzję i apropriację kulturową. Zdaniem badacza

${ }^{8} \mathrm{M}$. Foucault, Wiedza i władza, [w:] Współczesne teorie socjologiczne, t. 2, red. A. Jasińska-Kania, Warszawa 2006, s. 537-544.

${ }^{9}$ E.W. Said, Orientalizm, op. cit., s. 284-316.

${ }^{10}$ P. Hill Collins, Czarna myśl feministyczna w macierzy dominacji, [w:] Współczesne teorie..., op. cit., s. 1185-1196. 
zasadnicza różnica między wyzyskiem a nieopartym na wyzysku uciskiem polega na tym, że w stosunku wyzysku wyzyskiwacz potrzebuje wyzyskiwanego, ponieważ wyzyskiwacz zależy od wysiłku wyzyskiwanych. W przypadku ucisku nieopartego na wyzysku uciskający byliby szczęśliwsi, gdyby uciskani po prostu zniknęli. [...] Nie przypadkiem w Stanach Zjednoczonych funkcjonuje odrażające ludowe powiedzonko "dobry Indianin to martwy Indianin”, ale nie "dobry robotnik to martwy robotnik" albo "dobry niewolnik to martwy niewolnik"11.

Celem autora nie jest bynajmniej umniejszanie cierpienia czarnoskórych niewolników, wskazuje on jednak na szczególny charakter ucisku jako czegoś więcej niż tylko uprzywilejowanej pozycji społecznej, obecnej również w przypadku wyzysku. Można stwierdzić, że teoria Wrighta ma też przełożenie na obecną, postimperialną sytuację kultur grup wyzyskiwanych i uciskanych - o ile bowiem pierwsze musiały być "tolerowane” i rozwijały się zawsze w pobliżu reprezentantów grupy dominującej, o tyle te drugie „najlepiej” byłoby zlikwidować, co pozornie nie wiązałoby się z żadnymi kosztami dla cywilizacji uciskających.

$\mathrm{Na}$ koniec tego wprowadzenia teoretycznego warte wyjaśnienia są jeszcze dwie kwestie językowe. Pierwszą jest to, czemu uznano za stosowne używanie nie dosłownego tłumaczenia na język polski terminu appropriation („przywłaszczenie”), tylko zapożyczonego słowa „apropriacja”. Wynika to z faktu, że „przywłaszczenie” nie oddaje jednego z aspektów omawianego zjawiska. Zawsze implikuje bowiem aktywność osoby, która bezprawnie przypisuje sobie własność czegoś, co do niej nie należy. Tymczasem appropriation można też rozumieć jako „przypisanie”, a zatem jako sytuację, gdy pojawia się trzeci uczestnik interakcji, błędnie uznający, że sporny przedmiot (lub zwyczaj, obrządek czy wzór na kilcie) należy do kogoś innego niż jego faktyczny grupowy właściciel - co może, lecz nie musi wynikać z działań strony, której fenomen zostaje "nadany”. Można więc powiedzieć, że „apropriacja” obejmuje sytuację zarówno świadomego plagiatu, jak i losowego pomylenia autorstwa. Warto zauważyć, że jest to także związane z często wysuwaną propozycją, aby używać raczej zwrotu misappropriation, co dosłownie znaczyłoby „błędne przywłaszczenie lub przypisanie".

Druga uwaga dotyczy możliwej niejasności wynikającej z równoczesnego omawiania dwóch podejść do tego samego tematu. Jako że terminu

${ }^{11}$ E.O. Wright, Klasy się liczq, [w:] Współczesne teorie..., op. cit., s. 813-832. 
„apropriacja kulturowa” używa się prawie zawsze w odniesieniu krytycznym, czasem jest on zastępowany określeniem „krytyka” (oczywiście pod warunkiem, że z kontekstu łatwo się domyśleć, jakiego zjawiska ona dotyczy). Jednak ze względu na to, że w artykule przytaczane są również wypowiedzi negujące zasadność zwracania uwagi na omawiany tu fenomen, są one określane jako „krytyka apropriacji kulturowej”. Można mieć nadzieję, że wyjaśnienia te pozwolą na lepszą orientację w przedstawionej analizie.

Metodą wykorzystaną w badaniu była analiza materiałów internetowych pochodzących z popularnych stron: Twitter oraz Tumblr ${ }^{12}$. Oba źródła można zakwalifikować jako media społecznościowe, czyli portale służące do komunikowania się użytkowników, jednak każde z nich ma nieco inną charakterystykę, z której wynikły pewne różnice w sposobach zbierania materiałów. Wykorzystano przede wszystkim materiały anglojęzyczne ze względu na to, że angielski stanowi lingua franca internetu i wykorzystują go także osoby innego pochodzenia. Twitter słynie ze swojego ograniczenia do 140 znaków oraz powszechnego używania tagów ${ }^{13}$, można go także określić jako semianonimowy - chociaż wolno używać pseudonimów, bardzo częste jest podawanie faktycznych imion i nazwisk. Portal ten znany jest z aktywności firm, postaci ze świata kultury, a także polityki na swoich oficjalnych profilach. W badaniu materiałów $z$ tej strony zdecydowano się na wykorzystanie jedynie postów oryginalnych (czyli niestanowiących odpowiedzi na czyjąś wypowiedź), a także niebędących jedynie opisem do linku, chociaż zaakceptowano posty, w których to odsyłacze są dodatkiem do osobistej wypowiedzi. Zignorowano wreszcie te posty, w których otagowanie nie ma wyraźnego związku z treścią, co najprawdopodobniej oznacza, że tag służył jedynie zyskaniu popularności. Oprócz analizy treści danych zebranych z Twittera przeprowadzono powierzchowne badanie ilościowe. Ze względu na to, że portal pozwala na łatwe i pewne wyszukiwanie dat i tagów, dokonano liczebnego podsumowania postów otagowanych jako apropriacja kulturowa oraz skategoryzowano je jako popierające ten prąd

${ }^{12}$ Można zastanawiać się, dlaczego nie uwzględniono najbardziej popularnego medium społecznościowego, jakim wydaje się nadal być Facebook. Wynika to z faktu, że jego główną funkcją pozostaje utrzymywanie kontaktu z osobami, które zna się „w realu", a nie dyskusje na bardziej abstrakcyjne tematy z nieznajomymi.

${ }^{13}$ Dodanie symbolu \# przed danym zwrotem „oznakowuje” post jako dotyczący wybranego tematu. Tak oznaczony post będzie wyświetlał się wśród użytkowników, którzy szczególnie interesują się danym zagadnieniem, niezależnie od tego, czy obserwowany jest przez nich portal samego internauty. 
krytyczny, negujące go, wyrażające niezdecydowanie lub prośbę o udzielenie informacji na jego temat.

Druga ze stron wykorzystanych w badaniu, Tumblr, jest właściwie platformą mikroblogową, na której blogerzy mogą publikować swoje wpisy, reblogować inne, a także odpowiadać na stawiane sobie nawzajem pytania. Pytania te można zadawać, podpisując się swoim pseudonimem, jednak możliwe - i częste - jest także zadawanie pytań anonimowych, które niekiedy (w zależności od osobistych ustawień właściciela bloga) można zamieszczać nawet bez tworzenia profilu na portalu. Z wyjątkiem tej ostatniej możliwości Tumblr ma charakter pseudonimowy, czyli autorzy mogą być zidentyfikowani po swoich nickach, które mogą, lecz nie muszą odnosić się do faktycznych danych osobowych. Należy też podkreślić, że portal ten ma szerokie możliwości ustawień preferencji, z jakimi blogerami wchodzi się $w$ interakcje oraz jakie komentarze mogą pojawiać się pod wpisami autora. Strona ta oferuje możliwość pisania spersonalizowanych i pogłębionych tekstów, w związku z czym zdecydowano się „śledzić” w czasie badań tag "cultural-appropriation"14 i przytoczyć wypowiedzi, które uznano za najciekawsze lub cieszące się największym zainteresowaniem innych blogerów. Warto dodać, że w globalnej kulturze internetowej Tumblr słynie jako portal, którego użytkownicy skłaniają się ku skrajnie lewicowym poglądom, szczególnie w aspekcie kulturowo-społecznym.

Badania internetowe są nadal dosyć trudne w prowadzeniu, między innymi dlatego, że właściwie niemożliwe jest ustalenie, czy autor posta podpisałby się pod swoją wypowiedzią także „w realu”, a także czy podawane przez niego dane osobowe - $w$ tym związane $z$ przynależnością etniczną - są zgodne z prawdą (która, warto dodać, nie zawsze jest łatwa do jednoznacznego zidentyfikowania). Analizowanie w oparciu o tagi także nie należy do najpewniejszych form badań. Jak już zauważono, niektórzy użytkownicy oznaczają swoje wpisy w określony sposób tylko po to, by zyskać popularność. Warto też dodać, że tagowanie służy również umożliwieniu innym użytkownikom „odfiltrowania” danej treści. Poważnym problemem podczas badań internetowych są także boty, czyli programy sztucznej inteligencji „prowadzące” profile w mediach społecznościowych, co do których nie sposób stwierdzić, czy wyrażane przez nie poglądy mają

\footnotetext{
${ }^{14}$ Różnica w zapisie tagów wynika z ustawień stron internetowych: na Tumblrze używane są spacje, wyświetlane jako dywizy, natomiast na Twitterze w tagach nie używa się odstępów pomiędzy wyrazami.
} 
jakikolwiek związek z tymi popieranymi przez programistę. Badania w internecie, a szczególnie w mediach społecznościowych, utrudnia wreszcie łatwość usuwania profili lub zmieniania ich nazw i adresów ${ }^{15}$. Niemniej jednak wykorzystane materiały pozwalają się zorientować, jaki dyskurs otacza badane tu zjawisko apropriacji kulturowej. Nie negując konieczności ostrożnego traktowania danych internetowych, trzeba pamiętać, że internauci to między innymi studenci, dziennikarze, pisarze czy akademicy zajmujący się naukami społecznymi oraz kulturowymi i wykorzystujący nabytą wiedzę w swoich wpisach na blogach czy w mediach społecznościowych - ich wypowiedzi mogą więc mieć głębsze zaplecze uniwersyteckie. Wszystkie wpisy internetowe wykorzystane w badaniu pochodzą z okresu od 25 października do 25 listopada 2018 roku. Termin ten jest zarazem wyjątkowy i typowy w dyskusji nad apropriacją kulturową ze względu na przypadające w tym czasie Halloween i Święto Dziękczynienia - uroczystości, które wywołują dużo emocji wśród osób interesujących się omawianym zagadnieniem.

Zebrane materiały zdecydowano się przeanalizować przede wszystkim według podziału na pozytywne, neutralne lub negatywne ustosunkowanie do apropriacji kulturowej. Podstawą badania jest ilościowa i jakościowa analiza danych zebranych z Twittera, natomiast dłuższe wpisy z Tumblra służą głównie pogłębieniu tej tematyki.

W ciągu miesiąca od 25 października do 25 listopada 2018 roku można było znaleźć około 485 tweetów oznaczonych tagiem „culturalappropriation"16. Oprócz wpisów wyraźnie pozytywnie lub negatywnie odnoszących się do apropriacji kulturowej oraz pytań na ten temat wyróżniono dodatkową kategorię postów, które trudno było jednoznacznie zakwalifikować do którejś z wymienionych grup. Były to przede wszystkim wypowiedzi, które $w$ założeniu może miały być ironicznie, ale efekt ten nie jest wyraźny, a także te obracające omawiane tu zagadnienie przeciwko osobom, które je nagłaśniają, jednak bez jawnej złośliwości. Treści postów rozłożyły się stosunkowo równo wśród kategorii pozytywnych, negatywnych i trudnych

${ }^{15}$ Dotyczy to także części profili uwzględnionych w badaniu. Wszystkie nazwy i adresy przywołane w artykule są takie, jak w dniach 30-31 XI 2018 roku.

${ }^{16}$ Możliwe nieścisłości w liczbie postów wynikają między innymi z okazjonalnych powtórzeń tych samych wpisów lub problemów z połączeniem internetowym. W tagach na Twitterze nie oddziela się wyrazów, a podczas wyszukiwania nie jest brana pod uwagę wielkość liter. 
do określenia, chociaż pierwsza z nich pojawiła się najczęściej; stanowią one odpowiednio 37\%, $27 \%$ i $29 \%$ wziętych pod uwagę tweetów. Zdecydowanie najrzadziej zidentyfikowano wpisy mające charakter prostych, pozbawionych ironii pytań - stanowiły one tylko 7\% analizowanych wypowiedzi. Głównymi tematami, które stawały się punktem zapalnym dyskusji o apropriacji kulturowej, były wygląd, elementy ubioru, ale także kuchnia. Kwestia kultury niematerialnej była podnoszona o wiele rzadziej.

Chronologiczna analiza wpisów na Twitterze pozwala zauważyć, że różne wydarzenia w kulturze - głównie masowej, lecz także politycznej - stawały się przyczyną sporów wśród osób afirmujących i negujących zjawisko apropriacji kulturowej. Jak już wspomniano, w badanym okresie obchodzono dwa święta wywołujące dużo emocji wśród mieszkańców Stanów Zjednoczonych - Halloween oraz Święto Dziękczynienia (w 2018 roku przypadające 22 listopada). Szczególnie to pierwsze okazało się wyjątkowo bogate w komentarze na temat apropriacji kulturowej - tylko w dniach 31 października i 1 listopada ${ }^{17}$ napisano ich aż 135 (czyli ponad 25\% wszystkich analizowanych postów), przy czym również w okresie bezpośrednio je poprzedzającym i następującym po nich pojawiały się sporadyczne komentarze na ich temat. Kwestia strojów na Halloween (które w kulturze amerykańskiej pełni funkcję podobną do ostatków i chociaż dominują przebrania związane z horrorami i potworami, to nie są one normą) była przedmiotem największej liczby dyskusji dotyczących apropriacji kulturowej. Szczególnie drażliwy okazał się temat ubrań „inspirowanych” tradycjami rdzennych mieszkańców Ameryki Północnej, jednak pojawiała się też krytyka strojów zaczerpniętych z Bliskiego i Dalekiego Wschodu, Meksyku, a także mających odwzorowywać kulturę romską.

Trudno zaprzeczyć, że wszystkie zgłaszane przez osoby popierające apropriację kulturową przebrania bazowały na bardzo stereotypowym wizerunku wymienionych społeczności lub też seksualizowały tradycyjne stroje. Następujący post, połączony z linkiem do artykułu autorstwa rdzennej Amerykanki, zwraca uwagę na dodatkowy ciekawy aspekt, dosyć często podnoszony w tym kontekście: „Dziś Halloween... a oto felieton na @bustle o tym, dlaczego należy pomyśleć dwa razy o kostiumach, które się wybiera. Rdzenni Mieszkańcy ISTNIEJĄ" (wpis został też oznaczony

\footnotetext{
${ }^{17}$ Należy uwzględnić różnice czasowe pomiędzy Polską a USA, jak również pomiędzy Wschodnim a Zachodnim Wybrzeżem.
} 
interesującym tagiem \#NotYourPocahontas) ${ }^{18}$. To ostatnie zdanie wyraża uwagę, która często pojawia się w postach raportujących apropriację kulturową: traktowanie kultury niektórych grup etnicznych jako inspiracji dla strojów uprzedmiotawia je, ale też zaciera fakt, że te kultury są wciąż żywe i niektórzy ludzie się z nimi utożsamiają. Warto podkreślić, że kwestia utożsamienia łączy się tu z aspektem historycznym i rytualnym. Wątek ten jest rozwinięty w następującej odpowiedzi jednego z blogerów z Tumblra na anonimowe pytanie o opinię na temat analizowanego tu zagadnienia: „Kulturowa apropriacja faktycznie ma miejsce. Istnieją pewne przedmioty sakralne, których nie należy nosić, jak na przykład pióropusze. Jednak kimono już takim sakralnym przedmiotem nie jest. Problematyczne staje się, gdy seksualizuje się ten strój lub zakłada w celu kpiny"19. Interesująca była też uwaga, żeby nie utożsamiać Halloween z meksykańskim Día de Muertos $^{20}$. Poza postami zgłaszającymi przykłady apropriacji kulturowej większość wpisów to ogólne przypomnienia, aby uważać na ten problem, zwykle sformułowane nieagresywnie: „Przyjazne przypomnienie, że moja kultura nie jest waszym kostiumem w to Halloween. Po prostu powiedzcie «nie " kulturowej apropriacji”21. Szczególnie w dniach tuż przed świętem częste były też tweety utrzymane w podobnym tonie z załączonymi linkami lub infografikami, czym dokładnie jest omawiany tu problem i jak go unikać. Na uwagę zasługuje wreszcie post rzucający zupełnie inne światło na kwestię przebrań halloweenowych: „Fajnie jest przebierać się i udawać, że jest się kimś innym w Halloween. Niestety, niektórzy ludzie na wschodzie noszą "przebrania« i »udają " Metysów w pozostałe 364 dni roku"22.

Zdarzały się jednak także posty mogące wzbudzić bardziej mieszane uczucia wobec osób uważających apropriację kulturową za problem: „Proszę, pamiętajcie, aby ubrać się dziś w odpowiednie przebrania. Apropriacja

18 Jordan, @_NativelnLA, https://twitter.com/_NativeInLA/status/105761138891759 6161 (dostęp 30 XI 2018).

${ }^{19}$ Stop Making Liberals Look Bad!, https://stopmakingliberalslookbad.tumblr.com/ post/179965522395/whats-your-opinion-in-cultural-appropriation-i (dostęp 30 XI 2018).

${ }^{20}$ Felicity McKee, @flicknightshade, https://twitter.com/flicknightshade/status/1056 192430658277377 (dostęp 30 XI 2018).

${ }^{21}$ Alexis Tengesdal, @heartofascone, https://twitter.com/heartofascone/status/1057 340152358551552 (dostęp 30 XI 2018).

${ }^{22}$ Métis Nation News, @MetisNationNews, https://twitter.com/MetisNationNews/ status/1057714531361800192 (dostęp 30 XI 2018). 
kulturowa może powodować ciężką traumę. Torebka cukierków nie jest warta tego, aby ktoś inny musiał iść na terapię"23. Odchodząc od samego tematu Halloween, można znaleźć też takie tweety, jak ten wskazujący dosyć zaskakującą formę apropriacji kulturowej: „Rada od eksperta: nie ucz się języka, jeżeli nie pochodzisz od jego użytkowników, na przykład: nie ucz się francuskiego, jeśli nie jesteś Francuzem, nie ucz się islandzkiego, jeśli nie jesteś Islandczykiem. To tylko poszerza apropriację kulturową"24.

Można przypuszczać, że to wpisy podobne do powyższych przyniosły pewną niesławę tematowi apropriacji kulturowej, do tego stopnia, że Halloween 2018 roku niektórzy użytkownicy Twittera przezwali Dniem Apropriacji Kulturowej ${ }^{25}$. Pojawiały się też parodie kampanii mających uwrażliwić na stroje uznawane za przykłady tego zjawiska, nawołujące do tego, aby przebraniem nie drwić $z$ kultury... kotów ${ }^{26}$. Obok takich mniej lub bardziej zabawnych drwin najczęstszą formą krytyki apropriacji kulturowej było stosunkowo spokojne negowanie jej istnienia, poprzez twierdzenie, że jest ona po prostu dyfuzją i wymianą kulturową. Częste było też wskazywanie hipokryzji osób krytykujących przejmowanie elementów kulturowych przez jedne kultury, ale już nie inne. Szczególnym przypadkiem jest tu kwestia standardów urody, w których nadawanie sobie cech wyglądu przedstawicieli innej grupy etnicznej jest czasem uznawane za apropriację kulturową - jednak znacznie częściej jako hipokryzja postrzegana jest sytuacja, gdy to osoby rasy kaukaskiej nadmiernie się opalają lub noszą fryzury afro czy dready, niż gdy osoby ciemnoskóre sztucznie rozjaśniają cerę ${ }^{27}$. Podobnym zabiegiem jest też sprowadzanie tematu do absurdu, jak w następującym poście: „przykład apropriacji kulturowej: przedstawiciele LGBT ukradli tęczę Bogu, czy powinni ją oddać?"28.

\footnotetext{
${ }^{23}$ Nina Patrica Clarkson, @PatricaNina, https://twitter.com/PatricaNina/status/1057 618065020674050 (dostęp 30 XI 2018).

${ }^{24}$ Nat Peterson-Charles, @NigelPeterson, https://twitter.com/NigelPetersonC1/status/1057691586979659776 (dostęp 30 XI 2018).

${ }^{25}$ SLC not Utah, @SLCnotUTAH, https://twitter.com/SLCnotUTAH/status/10577993 95310100482 (dostęp 30 XI 2018).

${ }^{26}$ Alan Poirier, @alan_poirier, https://twitter.com/alan_poirier/status/1057863084 155518976 (dostęp 30 XI 2018).

27 Jolie LaPierre, @jolie_lapierre, https://twitter.com/jolie_lapierre/status/10650406 81440145408 (dostęp 30 XI 2018).

${ }^{28}$ NamJoonsEyelash, @exofan1489, https://twitter.com/exofan1489/status/106368 6127280775168 (dostęp 30 XI 2018).
} 
Zbliżoną formą argumentacji było również zwracanie uwagi na stare teksty kulturowe, na przykład westerny ${ }^{29}$, które najprawdopodobniej nie powstałyby $w$ atmosferze poprawności politycznej (aby sprawiedliwości stało się zadość, trzeba zwrócić uwagę, że o apropriację kulturową został oskarżony między innymi Elvis Presley $\left.{ }^{30}\right)$. W odniesieniu do Halloween często z kolei podkreślano, że teoretycznie jedynie Irlandczycy mają prawo obchodzić to święto, pojawiły się też rysunki satyryczne, w których spersonifikowana śmierć żąda zaprzestania odbierania jej kultury poprzez używanie wzorów szkieletów. Częstymi były również posty, których autorzy deklarowali, że nie przejmują się apropriacją kulturową, chociaż sami należą do mniejszości kulturowych lub narodów, których tradycyjne wyroby są powszechne na całym świecie (szczególnie wysuwali się tu na czoło Włosi). Najczęstszym argumentem było jednak twierdzenie, że ich inspiracja obcymi kulturami to nie apropriacja, tylko wyraz uznania ${ }^{31}$.

Ale również wśród krytyków apropriacji kulturowej zdarzały się wypowiedzi co najmniej szokujące, przede wszystkim sprowadzające zjawisko nie tyle do dyfuzji, ile do rasizmu, faszyzmu lub totalitaryzmu w stylu George’a Orwella ${ }^{32}$. Chyba jednak najbardziej szokującym postem był następujący: „Mieszanie się kultur jest dobre. Idea czystości kulturowej prowadzi do komór gazowych"33. Należy podkreślić, że w 2018 roku koncepcja apropriacji kulturowej ma już kilkuletnią karierę $w$ anglojęzycznym społeczeństwie internetowym, z czym wiąże się coraz agresywniejsze podejście do tematu reprezentantów obu stron dyskusji. Być może najtrafniejszym ujęciem obecnego stanu dyskursu o prawidłowym korzystaniu z elementów obcych kultur jest tweet napisany w samo Halloween: „Ten koleś dosłownie rzucił

${ }^{29}$ Jeff Reedstrom, @strurgisjeff, https://twitter.com/sturgisjeff/status/1058447752 621899777 (dostęp 30 XI 2018).

${ }^{30}$ Melissa Crook, @MissaVeggie, https://twitter.com/MissaVeggie/status/10635064 51166040065 (dostęp 30 XI 2018).

${ }^{31}$ Trevor Majors, @Trevor_Majors, https://twitter.com/Trevor_Majors/status/1062 108142216056833 (dostęp 30 XI 2018); w języku angielskim zachodzi gra słów: cultural appropriation - cultural appreciation.

${ }^{32}$ RapidFire, @Rapid_Fire1996, https://twitter.com/Rapid_Fire1996/status/105760 9319578042368 (dostęp 30 XI 2018).

${ }^{33}$ Brass, @Brass8782439, https://twitter.com/Brass87824349/status/106173152989 6980480 (dostęp 30 XI 2018). 
mnie na ziemię. Przyznaję, nie było zbyt mądre próbować zerwać mu kostiumowy pióropusz z głowy"34.

Niemniej jednak można natrafić także na przykłady szczerej chęci dialogu, ze strony zarówno osób reprezentujących kultury mniejszościowe, jak też otwartych członków grup dominujących. Przykładem może być muzyk zadający następujące pytanie: „Czy byłoby apropriacją kulturową, gdybym zagrał cover Bruno Marsa? Lub Jayz? Przy uwzględnieniu faktu, że jestem biały. Albo Eda Sheerana - przy uwzględnieniu, że jestem Niemcem. Jako artysta uliczny szczerze się niepokoję, że mógłbym kogoś urazić moim wyborem utworów"35.

W wypadku pogłębionych pytań i odpowiedzi na nie wyraźnie jednak lepiej przedstawia się Tumblr niż Twitter - co prawdopodobnie wynika między innymi z braku ograniczenia liczby znaków w poście. Można tam wskazać zarówno wypowiedzi wyjaśniające, jak można przeciwdziałać apropriacji kulturowej w delikatny sposób (zalecana metoda to zwrócenie uwagi dyskretnie, w cztery oczy lub za pomocą prywatnych komunikatorów) ${ }^{36}$, jak również posty przedstawiające synonimy terminów stanowiących dziedzictwo grup etnicznych ${ }^{37}$, czy wreszcie rozbudowane wypowiedzi na tak zapalny na Twitterze temat strojów halloweenowych, szczególnie tych dla dzieci, między innymi poprzez podkreślenie różnicy pomiędzy strojem fikcyjnej postaci a przebraniem mającym reprezentować historyczne realia ${ }^{38}$. Zwracają uwagę także posty tych, którzy poszukują własnej tożsamości etnicznej - na przykład po przejściu badania genetycznego - i proszą o pomoc w poznawaniu swoich korzeni ${ }^{39}$. Drugą stroną medalu są osoby, które są świadome swojego pochodzenia, jednak nie mają typowej dla niego urody - odczuwają one pewną niechęć do tematu apropriacji kulturowej,

${ }^{34}$ Lamar Kellywood, @lamarkellywood, https://twitter.com/lamarkellywood/status/ 1057663829931257856 (dostęp 30 XI 2018).

35 Ciizar D., @CiizarDofficial, https://twitter.com/CiizarDofficial/status/105542739541 3520384 (dostęp 30 XI 2018).

${ }^{36}$ Stop Making Liberals Look Bad!, https://stopmakingliberalslookbad.tumblr.com/ post/179622920640/so-an-internet-friendpenpal-dressed-up-as-a (dostęp 30 XI 2018).

${ }^{37}$ Little Urban Witch, http://little-urban-witch.tumblr.com/post/179630596895/ hey-so-in-the-spirit-of-not-appropriating-shit-on (dostęp 30 XI 2018).

${ }^{38}$ Feminism In Media, http://feminismandmedia.tumblr.com/post/179758205039/ about-the-dressing-up-thing-i-think-it-depends-on (dostęp 30 XI 2018).

${ }^{39}$ Little Lamb Lillianna, https://littlelamblillianna.tumblr.com/post/179727929335/ sticky-question (dostęp 30 XI 2018). 
ponieważ są o nią często niesłusznie oskarżane ${ }^{40}$. Posty takie wskazują na to, że przy zachowaniu pewnych norm etykiety - czy jak czasem się to nazywa: netykiety - dialog na temat tego, jak korzystać z ogólnoświatowych dóbr kulturowych z zyskiem dla wszystkich stron, jest możliwy. Na koniec warto jeszcze przytoczyć nieco bardziej przyziemną, ale trafną uwagę z Twittera: „jesteście korporacją i nie chcecie być krytykowani za kulturową apropriację. ZATRUDNIAJCIE daną społeczność. Zatrudniajcie ich artystów jako konsultantów, dajcie im pracę przy projekcie, darujcie część zysków, DOCENIAJCIE ich. Przestańcie udawać, że jesteście autorami danego pomysłu..."11. Być może więc rozwiązaniem problemu apropriacji kulturowej jest zwykłe okazywanie szacunku połączone $z$ materialnymi dowodami tego respektu.

Po zapoznaniu się z danymi zebranymi z Twittera i Tumblra trudno jest nie zadać podstawowego pytania: czy apropriacja kulturowa jest obiektywnie istniejącym problemem? Ostatecznie cała debata obraca się wokół zasadności podnoszenia tej kwestii, zwracania na nią uwagi, krytykowania cudzych zachowań i kontrolowania własnych. Wskazywano zachowania, które strukturalnie niewiele różnią się od tych dezaprobowanych jako apropriacja kulturowa, a jednak nie są potępiane przez jej krytyków. I należy powtórzyć to, o czym wspomniano na początku tekstu - pod względem obiektywnym faktycznie trudno jest odróżnić apropriację i dyfuzję kulturową. Nie oznacza to jednak, że apropriacja nie istnieje lub też że nie może być problemem - należy jedynie podkreślić, że należy ona raczej do porządku subiektywnego, psychologicznego niż obiektywnego i socjologicznego.

Rozważając apropriację kulturową, można zauważyć, że zagadnienie to składa się z kilku różnych aspektów, które należy postrzegać raczej jako kwestie indywidualnej wrażliwości, subiektywnej oceny, choć dąży się do ich ujednolicenia i obiektywizacji. Być może część winy ponosi tu pozytywistyczny nurt w naukach społecznych, dążący do ich jak największego zbliżenia do wiedzy ścisłej, zarazem nieświadom własnych skrzywień i uprzedzeń. Pewną rolę odgrywa tu jednak także nadrzędność prawa względem innych elementów życia społecznego, na którą uwagę zwracają Comaroffowie. Zderzenie się zachodniego prawa autorskiego z obyczajami innych

${ }^{40}$ Green Witchy Mama, https://green-witchy-mama.tumblr.com/post/179758987784/ short-vent-into-the-void (dostęp 30 XI 2018).

${ }^{41}$ Mariela R., @marielaregal, https://twitter.com/marielaregal/status/106602832957 1102721 (dostęp 30 XI 2018). 
grup kulturowych wymaga podporządkowania, podzielenia tych ostatnich w kategorie łatwo interpretowalne dla przepisów. Można więc powiedzieć, że jednym ze skutków niezrównoważonych stosunków władzy jest obecnie konieczność analizowania samych stosunków władzy - jeżeli bowiem pewne przywileje przysługują jedynie grupom uciskanym, to trzeba ustalić jednoznaczną definicję ucisku. Podobnie aby ustalić, kto może z tych przywilejów korzystać, należy wyznaczyć kategorie określające przynależność do takiej społeczności - czemu współczesność zawdzięcza ogromną karierę badań genealogicznych. Jak można było zauważyć w niektórych postach, te ostatnie mogą prowadzić nie tylko do legalnego przypisania do grupy etnicznej, ale także, wolno powiedzieć, do „stworzenia tożsamości” danej osoby, skłonienia jej do przemiany poprzez odkrycie jej korzeni.

Należy się zresztą zastanowić, czy kwestia poszukiwania tożsamości nie jest główną przyczyną jeżeli nie powstania, to popularności rozważań nad apropriacją kulturową. Nie jest zapewne przypadkiem, że na temat ten szczególnie uwrażliwieni są mieszkańcy Stanów Zjednoczonych, państwa założonego przez emigrantów - zarówno dobrowolnych, jak i przymuszonych do przyjazdu - na terenach zamieszkiwanych przez ludzi o bogatej kulturze, która jednak ze względu na swój niematerialny charakter była zwykle lekceważona przez kolonistów. Zwraca uwagę, że w argumentach przeciwników apropriacji kulturowej często podnosi się kwestię „melting potu", mającego niezaprzeczalnie wysoką pozycję w identyfikacji tożsamości amerykańskiej - a przynajmniej sławetnego WASP-a, białego anglosaksońskiego protestanta (white anglo-saxon protestant). Z deklaracji innych grup kulturowych wynika bowiem, że oczywistość tygla kulturowego nie jest tak oczywista, jak sugerowałaby wyżej zaprezentowana wiedza-władza. Nie jest brane pod uwagę, czy na pewno wszyscy ci, których kultury były „stapiane” w Ameryce Północnej, byli temu przychylni. Można wprawdzie argumentować, że decyzja emigracji implikowała zgodę na warunki stawiane w „ziemi obiecanej”, jednak należy pamiętać, że przenosiny na jej teren często wynikały z konieczności ekonomicznych lub politycznych, a nie ze zwykłej chęci. Sytuacja rdzennych ludów, jak również potomków niewolników jest jeszcze bardziej skomplikowana (a może właśnie prostsza?) ze względu na to, że raczej o nich nie myślano, gdy powstawała koncepcja tygla kulturowego - jeżeli do niego trafili, to - by użyć fizycznego porównania - siłą rozpędu.

Na pewną refleksję zasługuje też ostra uwaga krytyków apropriacji kulturowej, uznających ją za formę rasizmu. Chociaż trudno się zgodzić z tym 
porównaniem, można stwierdzić, że istnieje element wrogości w oddzielaniu od siebie różnych grup w oparciu o cechy kulturowe, czasem przybierający agresywne formy, choć widać, że zależy to raczej od indywidualnego temperamentu niż cech samej kultury. Trzeba jednak stwierdzić, że wynika to zwykle nie z niechęci do innych kultur, etniczności czy religii, ale z oporu wobec tego, co wszystkie bardziej rozbudowane definicje apropriacji kulturowej podkreślają: dominacji.

Lecz jaka jest kultura obecnie dominująca? Czy jest to po prostu kultura białych, amerykańska, chrześcijańska, ateistyczna, czy może ogólnie zachodnia? Odpowiedź jest zarazem mniej i bardziej skomplikowana - obecnie dominuje przede wszystkim kultura masowa. Można powiedzieć, że apropriacja kulturowa jest terminem stworzonym przez barberowski „Dżihad” w znaczeniu reakcji obronnej na "McŚwiat"42. Atakuje się solaria i czarnoskóre aktorki rozjaśniające włosy, lecz celem tego ataku są zhomogenizowane standardy urody. Krytykuje się „indiańskie” stroje na Halloween, lecz chodzi tu głównie o masową profanację etnicznego sacrum. Można nawet powiedzieć, że samo Halloween dawno przestało być czy celtycką spuścizną, czy amerykańską uroczystością, a stało się przede wszystkim świętem zmarłych w wydaniu globalnej komercji. Być może więc odrzucanym przez osoby promujące apropriację kulturową jest nie tyle kulturowy tygiel, ile kulturowy zestaw Happy Meal?

Warto jest się także zastanowić, czy europejska emigracja do Stanów Zjednoczonych nie stworzyła pewnego ideału czy raczej tworu wiedzy-władzy, obejmującego to, jak „powinny” wyglądać relacje w społeczeństwie wielokulturowym, a także jacy „powinni” być emigranci. Nie sposób jednak wymagać, aby wszystkie mniejszości kulturowe podporządkowały się jednemu standardowi współżycia, przynajmniej nie z uszanowaniem ich wewnętrznych zwyczajów - jeżeli z żadnej innej przyczyny, to dlatego, że właśnie one mogą ograniczać kontakty z innymi społecznościami. Czy oznacza to, że kultura kulturze jednak nierówna?

W pewnym sensie tak - przy uwzględnieniu, że równość zawsze musi być względem czegoś. Dyskurs na temat apropriacji kulturowej - po obu stronach dyskusji - wydaje się często mieszać porządek legalny z obyczajowym. O ile bowiem w tym pierwszym faktycznie konieczne jest określenie obiektywnych kryteriów, o tyle w drugim zarówno reguły, jak i ewentualne

${ }^{42}$ Zob. B.R. Barber, Dżihad kontra McŚwiat, przeł. H. Jankowska, Warszawa 2013. 
sankcje mają bardziej elastyczny charakter. Raczej więc bardziej niż odnosić się do jednoznacznych wyznaczników apropriacji kulturowej lub kodeksów zachowań podczas uroczystości, należałoby wypracować normy wzajemnego szacunku pomiędzy różnymi grupami kulturowymi. Nie pomogą w tym ani prowokacyjne zdjęcia osób chwalących się swoimi umyślnie tandetnymi „etnicznymi” strojami, ani porównywanie apropriacji kulturowej do segregacji rasowej - ale też nie pomogą agresywne ataki na każdy tekst kultury masowej choćby odlegle czerpiący z grup marginalizowanych. Nie sprawdza się też przemawianie w imieniu całej wspólnoty, obecne po obu stronach dyskusji. To, że reprezentanci jednej kultury nie czują się urażeni wykorzystywaniem jej elementów, nie znaczy, że musi to dotyczyć wszystkich innych - ale nie należy też generalizować własnej wrażliwości na całą społeczność. Być może jedynym rozwiązaniem jest zadawanie jak największej liczby pytań, co - jak się okazało podczas badań - stanowi najrzadziej występujący rodzaj wypowiedzi internetowych na temat apropriacji kulturowej.

Sytuacja z pewnością jest skomplikowana, gdyż na naszych oczach kształtuje się szczególny rodzaj społeczeństwa globalnego. Można się zresztą pokusić o stwierdzenie, że być może na tym właśnie polega największa zasługa dyskusji o apropriacji kulturowej - samo zwracanie na nią uwagi pozwala głębiej uzmysłowić sobie nieoczywistość oczywistości. Należy mieć nadzieję, że w połączeniu z pokorą z jednej, a dobrą wolą z drugiej strony pozwoli ona zarówno na faktycznie głębokie poznawanie różnych zwyczajów, jak i na wypracowanie szczególnego savoir-vivre’u współżycia kultur o różnej przeszłości w połączonej internetową siecią globalnej społeczności.

\section{BIBLIOGRAFIA}

Banaś M., Etniczność na sprzedaż, Kraków 2005.

Barber B.R., Dżihad kontra McŚwiat, przeł. H. Jankowska, Warszawa 2013.

Comaroff J.L., Comaroff J., Etniczność sp. z o.o., przeł. W. Usakiewicz, Kraków 2011.

Foucault M., Wiedza i władza, [w:] Współczesne teorie socjologiczne, t. 2, red. A. Jasińska-Kania, Warszawa 2006, s. 537-544.

Hill Collins P., Czarna myśl feministyczna w macierzy dominacji, [w:] Współczesne teorie socjologiczne, t. 2, red. A. Jasińska-Kania, Warszawa 2006, s. 1185-1196.

Lisowska-Magdziarz M., Analiza tekstu w dyskursie medialnym. Przewodnik dla studentów, Kraków 2006. 
Said E.W., Orientalizm, przeł. M. Wyrwas-Wiśniewska, Poznań 2005.

Słownik etnologiczny: terminy ogólne, red. Z. Staszczak, Warszawa - Poznań 1987.

Wright E.O., Klasy się liczq, [w:] Współczesne teorie socjologiczne, t. 2, red. A. Jasińska-Kania, Warszawa 2006, s. 813-832.

\section{Netografia}

Bradford K.T., The Cultural Appropriation Primer, https://medium.com/@tempest/the-cultural-appropriation-primer-91f1101dae1d (dostęp 28 XI 2018).

Cambridge Dictionary, https://dictionary.cambridge.org/dictionary/english/cultural-appropriation (dostęp 28 XI 2018).

Tumblr.com:

Feminism In Media, http://feminismandmedia.tumblr.com/post/179758205039/about-the-dressing-up-thing-i-think-it-depends-on (dostęp 30 XI 2018).

Green Witchy Mama, https://green-witchy-mama.tumblr.com/post/179758987784/short-vent-into-the-void (dostęp 30 XI 2018).

Little Lamb Lillianna, https://littlelamblillianna.tumblr.com/post/179727929335/sticky-question (dostęp 30 XI 2018).

Little Urban Witch, http://little-urban-witch.tumblr.com/post/179630596895/hey-so-in-the-spirit-of-not-appropriating-shit-on (dostęp 30 XI 2018).

Stop Making Liberals Look Bad!, https://stopmakingliberalslookbad.tumblr.com/post/1796 22920640/so-an-internet-friendpenpal-dressed-up-as-a (dostęp 30 XI 2018).

Stop Making Liberals Look Bad!, https://stopmakingliberalslookbad.tumblr.com/post/1799 65522395/whats-your-opinion-in-cultural-appropriation-i (dostęp 30 XI 2018).

Twitter.com:

Alan Poirier, @alan_poirier, https://twitter.com/alan_poirier/status/1057863084155518976 (dostęp 30 XI 2018).

Alexis Tengesdal, @heartofascone, https://twitter.com/heartofascone/status/10573401 52358551552 (dostęp 30 XI 2018).

Brass, @Brass8782439, https://twitter.com/Brass87824349/status/1061731529896980480 (dostęp 30 XI 2018).

Ciizar D., @CiizarDofficial, https://twitter.com/CiizarDofficial/status/1055427395413520384 (dostęp 30 XI 2018).

Felicity McKee, @flicknightshade, https://twitter.com/flicknightshade/status/1056192430 658277377 (dostęp 30 XI 2018).

JeffReedstrom, @strurgisjeff, https://twitter.com/sturgisjeff/status/1058447752621899777 (dostęp 30 XI 2018).

Jolie LaPierre, @jolie_lapierre, https://twitter.com/jolie_lapierre/status/106504068144014 5408 (dostęp 30 XI 2018).

Jordan, @_NativelnLA, https://twitter.com/_NativelnLA/status/1057611388917596161 (dostęp 30 XI 2018).

Lamar Kellywood, @lamarkellywood, https://twitter.com/lamarkellywood/status/105766 3829931257856 (dostęp 30 XI 2018).

Mariela R., @marielaregal, https://twitter.com/marielaregal/status/1066028329571102721 (dostęp 30 XI 2018).

Melissa Crook, @MissaVeggie, https://twitter.com/MissaVeggie/status/10635064511660 40065 (dostęp 30 XI 2018). 
MétisNation News, @MetisNationNews, https://twitter.com/MetisNationNews/status/1057 714531361800192 (dostęp 30 XI 2018).

NamJoonsEyelash, @exofan1489, https://twitter.com/exofan1489/status/10636861272807 75168 (dostęp 30 XI 2018).

Nat Peterson-Charles, @NigelPeterson, https://twitter.com/NigelPetersonC1/status/10576 91586979659776 (dostęp 30 XI 2018).

Nina Patrica Clarkson, @PatricaNina, https://twitter.com/PatricaNina/status/10576180650 20674050 (dostęp 30 XI 2018).

RapidFire, @Rapid_Fire,https://twitter.com/Rapid_Fire1996/status/1057609319578042368 (dostęp 30 XI 2018).

SLC not Utah, @SLCnotUTAH, https://twitter.com/SLCnotUTAH/status/1057799395310100482 (dostęp 30 XI 2018).

Trevor Majors, @Trevor_Majors, https://twitter.com/Trevor_Majors/status/10621081422 16056833 (dostęp 30 XI 2018).

\title{
IDENTITY, DOMINANCE AND INTERNET - CULTURAL APPROPRIATION IN ON-LINE DISCOURSE
}

\begin{abstract}
Intensification of international contacts during globalisation allowed for mutual understanding and inspiration between representatives of different cultures. Nevertheless, the line between inspiration and copying other cultures' elements appears thin, unnoticeable in comparison to financial gains from customs' commercialisation. This topic is discussed in the West as cultural appropriation. The goals of this article were to see what behaviours are perceived as appropriation and if it is perceived as an intercultural problem. The research, conducted on social media, indicates that cultural appropriation is a problematic topic, however the will to define it and treat as intercultural power abuse is increasing.
\end{abstract}

Key words: cultural appropriation, neo-colonialism, post-colonialism, globalisation, power 